\title{
Investigating the Diversity and Variability of Eastern Mediterranean Landscapes
}

\author{
Ioannis N. Vogiatzakis * and Paraskevi Manolaki \\ School of Pure \& Applied Sciences, Open University of Cyprus, PO Box 12794, 2252 Nicosia, Cyprus; \\ paraskevi.manolaki@ouc.ac.cy \\ * Correspondence: ioannis.vogiatzakis@ouc.ac.cy; Tel.: +357-22411933
}

Received: 31 August 2017; Accepted: 17 October 2017; Published: 20 October 2017

\begin{abstract}
The aim of the paper is to examine the variability of eastern Mediterranean landscapes using a common mapping framework relying on Landscape Character Mapping (LCM). LCM was adapted to the region's specificities placing emphasis on the area's coastal nature, landform variation, land use, in particular pastoral tradition, and settlement patterns, an important output of this study. We selected six study areas, in four countries namely Cyprus, Greece, Jordan and Lebanon, based on their rich cultural and natural heritage, covering a NW to SE gradient of both environmental and cultural settings. We used commonly employed landscape metrics to quantify landscape diversity in the study areas. Similarity in landscape types among study area was measured using Sørensen similarity index. The Kruskall-Walis test was used to test the variability among countries in terms of landscape character variation due to physical and cultural factors. Linear regression was used to assess whether landscape diversity increases with area size. The work has identified and mapped a total of 69 landscape types, of which 18 are rare. Rare landscape types were related to specific geomorphology or intensive anthropogenic activities, which do not occur elsewhere in the East Mediterranean region. The highest similarity was recorded between islands and between mountainous areas. The larger the area the higher is its landscape diversity. This works fills a gap in Mediterranean and sets a benchmark standard for landscape characterization work in the East Mediterranean, so as to enable much greater consistency between countries in future landscape mapping exercises and, ultimately, facilitate trans-boundary cooperation in landscape-scale nature and culture conservation.
\end{abstract}

Keywords: classification; GIS; LCA; Land Description Units; mapping; planning; typology

\section{Introduction}

Landscape diversity is considered the fourth form of diversity [1] which, in landscape ecology, equates to heterogeneity, and underpins much of the work in that discipline [2]. According to PEBDLS "landscape diversity is the formal expression of the numerous relations existing in a given period between the individual or a society and a topographically defined territory, the appearance of which is the result of the action, over time, of natural and human factors and a combination of both" [3]. This definition provides the foundation for the explanation of landscape diversity of the Mediterranean Basin (MB), a coherent geographical region, which includes parts of three continents Europe, Asia and Africa. In the Mediterranean the diverse climate, geology and topography and the intense and long human footprint has resulted in a rich mosaic of cultural landscapes that characterizes so much of the basin [4-6].

Due to the common underlying factors, which have shaped its landscapes, the MB is often considered a relatively homogeneous area. Although it is true to a certain extent that many landscapes of common character are present, there are also many others, which are very different, often as a result of extreme gradients (natural or anthropogenic) which can be recognized in the area. The perceived overall uniformity of the area holds well and has been demonstrated for biological and cultural 
diversity [5-8] but has never really been quantified for landscape diversity. Many of these landscapes are so typical throughout the Mediterranean to the extent that inhabitants and visitors alike can resonate with their distinct character.

The landscapes of the Mediterranean Basin (MB) also experience common pressures, such as rapid change due to urbanisation, rural depopulation, decreased rainfall, increased fire frequency, tourism expansion, social inequalities, political instability, etc. Historically, the area has demonstrated a tendency to adaptation to new socioeconomic and environmental challenges and as such, a great variety of landscapes has been created, but the rate of change may now exceed their resilience. Thus, there is a need to develop appropriate tools to assess and monitor change and to make reasonable judgment about the condition of the landscape and its capacity to change.

The emergence of landscape on the political agenda (e.g., [9-11]) culminated with the European Landscape Convention (ELC) [12]. The ELC calls for the identification of distinct landscape types within a country, assessment of landscapes, understanding landscape change, and develop landscape quality objectives in partnership with stakeholders [13]. Landscape Characterization is an environmental stratification [14] which attempts to summarize environmental variation in the landscape, but is quite distinct to existing stratification schemes since it generally relies on the identification of meaningful landscape units recognizable in the field rather than arbitrary grid cells (but see [15]). By now there is more than one way to carry out Landscape Character Assessment (LCA) in Europe, each of which comes with its own tools and trade-offs $[16,17]$. LCA has become more complex and holistic over the years with methods ranging from simple-interpretative or mechanistic-analytical to more complex analytical and/or interactive methods $[18,19]$. These usually lead in a hierarchical system, which allows for upscaling, and downscaling and can be applied in environmental monitoring and policy development $[15,17]$.

In this study, we ask how diverse the landscapes in the Eastern Mediterranean (EastMed) region are, and to what extent the landscapes encountered, are similar among the EastMed countries. In order to do that, we relied on a common mapping framework developed under the MEDSCAPES project, based on the principles of Landscape Character Assessment (LCA) employed in northern Europe. MEDSCAPES, a 2-year project funded by the ENPI-CBCMED program, aimed at the development of LCA as a tool for effective conservation of natural heritage in the Eastern Mediterranean. The project's specific objectives were (a) to develop and apply a best-practice methodology for identifying, mapping and assessing Landscape Character in pilot areas, and (b) to promote the results as a tool for sustainable land use decision-making and landscape-scale protection of the natural and cultural heritage in the East Mediterranean context.

Despite the fact that by now most of the Euro-Mediterranean countries (e.g., Portugal Spain, Italy, Slovenia) have produced a national landscape typology, these are not directly comparable since they all use very different mapping frameworks and often different philosophies to delineate landscapes (see review [20]). At the same time, and while some regional classifications account, to a certain extent, for Mediterranean landscapes $[15,21]$, they rely on generalized patterns often of solely biophysical variables ignoring Mediterranean specificities. None of these have attempted an account of the variation of Mediterranean landscapes at the regional level i.e., they have not been developed explicitly for the Mediterranean region, with the exception of a recent study on land systems [22].

The idea of the present study is to take MEDSCAPES project results a step further and to test the potential of a common landscape mapping framework for assessing and comparing landscape diversity between different countries in the East Mediterranean area. The importance of such work is that it will set a benchmark standard for landscape characterization in the East Mediterranean, so as to enable greater consistency between territories of the Basin in future landscape mapping exercises and, ultimately, facilitate trans-boundary cooperation in landscape-scale nature and culture conservation. 


\section{Materials and Methods}

\subsection{Study Area-East Mediterranean Basin}

Six study areas in four different east Mediterranean countries were selected (Table 1; Figure 1). Their selection was based on their rich cultural and natural heritage, to represent a biogeographical gradient (NW to SE), but also a gradient of both environmental and cultural settings. Therefore, it encompasses both islands and continental areas, including mountains, arid and semi-arid areas, but also the imprints of Muslim and Christian traditions, as well as archaeological evidence of past civilizations, all typical of the Mediterranean character:

(a) Cyprus: the study area includes the whole of the island, the third largest in the Mediterranean. The island is divided into three geomorphological zones, the Troodos Mountain, the Pentadaktylos Range and the Mesaoria plain with rugged morphology and varied geology. The climate is, in general at the drier end of the Mediterranean-type climates. The rural landscape is dominant and usually intermixed with natural elements.

(b) Mujib (Jordan): the study area is located within Madaba and Kerak governorates. The area extends from the Jordan Rift Valley (JRV) escarpment in the west at $420 \mathrm{~m}$ below sea level to the central highlands plateau in the east with elevations exceeding $700 \mathrm{~m}$ above sea level.

(c) Al Yarmouk (Jordan): the study area is located in the NW part of Jordan. Al Yarmouk catchment area has high relief topography with elevations from about 26 m.b.s.l. to about 1200 m.a.s.1. The catchment comprises of large urban centers (Irbid and Al Ramtha) in addition to extensive agricultural activities (around $50 \%$ of the total catchment area).

(d) Epirus (Greece): the study area is predominantly mountainous characterized by significant landscape diversity. High mountains with dense forest cover below $1700 \mathrm{~m}$ and alpine meadows at their peaks are traversed by wide cultivated valleys and steep unsettled gorges; cultivated, settled areas and extensive grazed pastures.

(e) Lesvos (Greece): the study area includes the whole of the island, the third largest in the Aegean Sea. Agriculture and tourism are the main economic activities on the island. Approximately $41.3 \%$ of the island's surface is olive plantations, $34 \%$ maquis and garrigue, $17 \%$ forest, $4.3 \%$ other crops, while the remaining land has various uses such as constructions, wetlands, etc.

(f) Lebanon: the study area is approximately $4747.40 \mathrm{~km}^{2}, \mathrm{c} .45 \%$ of the total area of the country. It contains 15 cazas that reach an altitudinal range of $1700 \mathrm{~m}$, with exceptions of high peaks in mountainous areas, and low altitudes in deep valleys. Moreover, it encompasses four distinct geomorphological regions, which are: coastal plain, Lebanon mountain range, Bekaa valley, and the Anti-Lebanon mountain range. 
Table 1. Main characteristics of the study sites and the datasets used in Landscape Character Mapping.

\begin{tabular}{|c|c|c|c|c|c|}
\hline \multirow{2}{*}{ Natural and Cultural Features of the Study Areas } & \multirow{2}{*}{ Area $\left(\mathrm{km}^{2}\right)$} & \multicolumn{4}{|c|}{ Sources of Information for the Desk Study } \\
\hline & & Geology & Landform & Landuse-Land Cover & Settlement \\
\hline $\begin{array}{l}\text { Cyprus: the islands is a global biodiversity hotspot and is } \\
\text { located on a bird migratory route. There are } 38 \text { terrestrial Sites } \\
\text { of Conservation Importance at the EU level (i.e., Natura } \\
2000 \text { sites) while c. } 60 \% \text { of its territory comprises high nature } \\
\text { value farmlands important for biodiversity support. Cyprus is } \\
\text { also rich archaeological sites as well as religious sites (Christian } \\
\text { and Muslim). }\end{array}$ & 9251 & $\begin{array}{l}\text { Geological map } \\
\quad(1: 250,000)\end{array}$ & $\begin{array}{l}20 \mathrm{~m} \text { contours-derived } \\
\text { from USGS Global (DEM) }\end{array}$ & Corine & $\begin{array}{ll}\text { - } & \text { Village Settlement Data: } \\
\text { villages clusters } \\
\text { - } \quad \text { Village Settlement Data: } \\
\text { village compactness } \\
\text { - } \quad \text { Field Patterns }\end{array}$ \\
\hline \multirow{2}{*}{$\begin{array}{l}\text { Mujib (Jordan): As part of the Jordan, Rift Valley (JRV) the } \\
\text { area in along an important global bird migration flyway. It is } \\
\text { one of the most remarkable nature and biodiversity areas of } \\
\text { interest in Jordan, with one Protected Area and two Special } \\
\text { Conservation Areas The area is also known for its cultural and } \\
\text { religious value, and is one of the most visited adventure and } \\
\text { therapeutic tourism destinations in Jordan. Large part of the } \\
\text { Area is a UNESCO Man and the Biosphere Reserve }\end{array}$} & \multirow[b]{2}{*}{4207} & \multirow[b]{2}{*}{$\begin{array}{c}\text { Geological map of Jordan } \\
(1: 250,000)\end{array}$} & \multirow[b]{2}{*}{$\begin{array}{c}\text { Topographic maps } \\
(1: 50.000)\end{array}$} & \multirow[b]{2}{*}{$\begin{array}{c}\text { National Land Cover Map } \\
\text { 1:250,000 }\end{array}$} & Google Earth \\
\hline & & & & & Topographic Maps \\
\hline \multirow{2}{*}{$\begin{array}{l}\text { Al Yarmouk (Jordan): The area includes a Special } \\
\text { Conservation Area, a forest reserve while it is also rich in } \\
\text { scenic, historical, and cultural elements, including remains of } \\
\text { uninterrupted occupation since the Neolithic Period and the } \\
\text { ancient city of Gadara (Umm Quais) }\end{array}$} & \multirow[b]{2}{*}{1390} & \multirow[b]{2}{*}{$\begin{array}{c}\text { Geological map of Jordan } \\
(1: 250,000)\end{array}$} & \multirow[b]{2}{*}{$\begin{array}{l}30 \mathrm{~m} \text { DEM (ASTER) } \\
\text { Global Digital Elevation } \\
\text { Model ver. 2; } 30 \mathrm{~m} \\
\text { contours }\end{array}$} & \multirow[b]{2}{*}{$\begin{array}{c}\text { National Land Cover Map } \\
\text { 1:250,000 }\end{array}$} & Google Earth \\
\hline & & & & & Topographic Maps \\
\hline Epirus (Greece): The rich natural heritage of the area, which & \multirow[b]{2}{*}{3908} & \multirow[b]{2}{*}{ Geological map of Epirus } & \multirow[b]{2}{*}{$\begin{array}{l}\text { Topographic map, } \\
\text { contours per } 50 \mathrm{~m} \text { (Aster } \\
\text { Global DEM) } 20 \mathrm{~m} \text { ) }\end{array}$} & \multirow[b]{2}{*}{$\begin{array}{l}\text { CORINE land-cover } \\
(1: 250,000) \text {, geodata.gov }\end{array}$} & Google Earth \\
\hline $\begin{array}{l}\text { Vikos-Aoos (both important nationally for their floristic } \\
\text { diversity), is complemented by its significant historic and } \\
\text { cultural heritage, characteristically portrayed through the } \\
\text { plethora of traditional settlements, stone bridges and footpaths. } \\
\text { Vikos-Aoos is a UNESCO Global Geopark and one of the last } \\
\text { European stongholds of the brown bear }\end{array}$ & & & & & Topographic Maps \\
\hline
\end{tabular}


Table 1. Cont

\begin{tabular}{|c|c|c|c|c|c|}
\hline \multirow{2}{*}{ Natural and Cultural Features of the Study Areas } & \multirow{2}{*}{ Area $\left(\mathrm{km}^{2}\right)$} & \multicolumn{4}{|c|}{ Sources of Information for the Desk Study } \\
\hline & & Geology & Landform & Landuse-Land Cover & Settlement \\
\hline $\begin{array}{l}\text { Lesvos (Greece): Contains } 34 \% \text { surface cover of maquis and } \\
\text { garrigue, } 17 \% \text { forest, and important wetlands. The architecture } \\
\text { is particularly rich in legacy and styles and showcases cultural } \\
\text { influences from the East (Ottoman Empire) and from the West } \\
\text { (Europe). Natural and other monuments and historical sites: } \\
\text { The Petrified Forest of Sigri and cultural monuments (i.e., the } \\
\text { Castle of Sigri). Religious monuments: the Ypsilou Monastery } \\
\text { and the Monastery of Pithariou. Archaeological Sites: Fortress } \\
\text { of Sigri, Eresos Acropolis, Monastery High, Pithariou } \\
\text { Monastery. Traditional settlements: Vatoussa }\end{array}$ & 1795 & $\begin{array}{l}\text { Geological map of Lesvos } \\
\text { (1:250,000), UoA }\end{array}$ & $\begin{array}{l}\text { Topographic map, } \\
\text { contours per } 50 \mathrm{~m} \\
(1: 250,000) \text { UoA }\end{array}$ & $\begin{array}{l}\text { CORINE land-cover } \\
(1: 250,000) \text {, geodata.gov }\end{array}$ & $\begin{array}{l}\text { Ordnance survey map } \\
(1: 250,000) ; \text { geodata.gov }\end{array}$ \\
\hline $\begin{array}{l}\text { Lebanon: the study area includes three Man and the Biosphere } \\
\text { Reserves, more than } 10 \text { nationally designated protected areas } \\
\text { and biodiversity hotpspots such as the Lebanon and } \\
\text { Anti-Lebanon mountains, as well as Byblos (Jbeil) a World } \\
\text { Heritage Site }\end{array}$ & 4757 & Geological map & $\begin{array}{l}50 \text { m contour maps; } \\
\text { Topographic map }\end{array}$ & Land cover map $(1: 20,000)$ & Settlement map \\
\hline
\end{tabular}




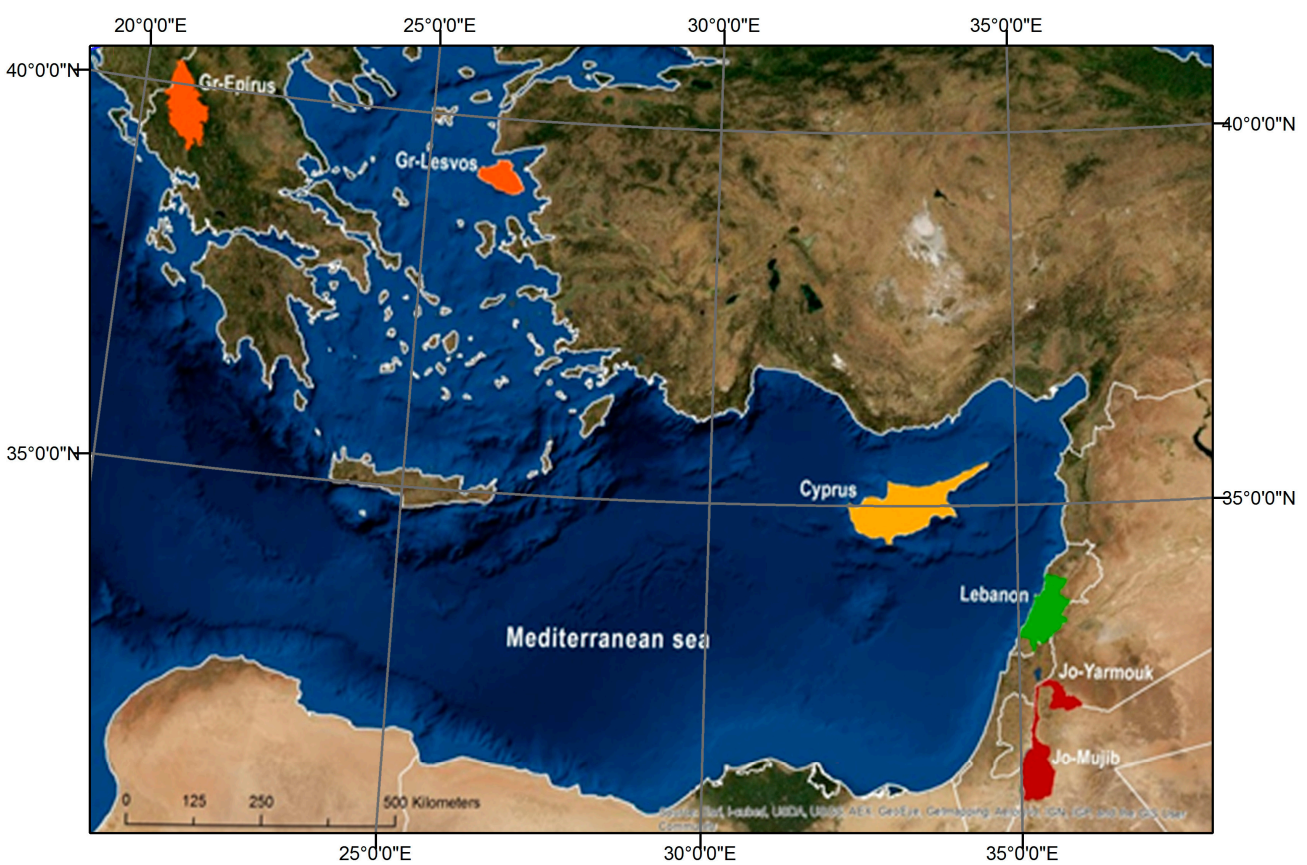

Figure 1. Location of the six study areas, different color indicates study areas located in different countries (from west: Orange = Greece; Yellow = Cyprus; Green = Lebanon and Red = Jordan).

\subsection{Landscape Character Mapping}

The study involved review and evaluation of the LCA methodology in the context of its original principles and objectives as developed and applied in the U.K. The evaluation considered how improvements and additions in the steps involved in UK_LCA methodology will increase subjectivity in the process and better measure the heterogeneity of the eastern Mediterranean landscapes, as described below (Figure 2).

\section{Establishment of Working Framework}

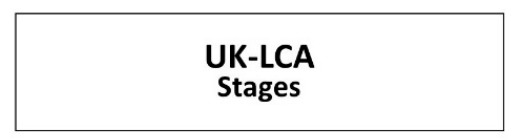

Step 1: Defining the scope

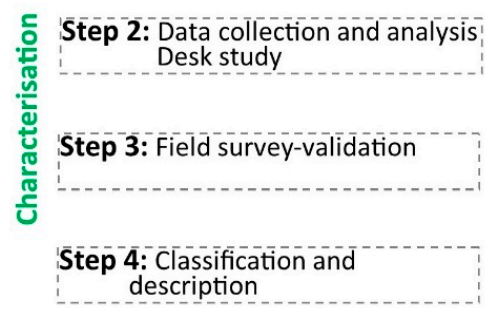

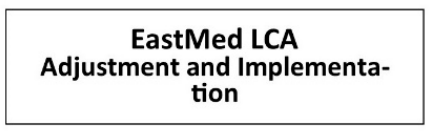

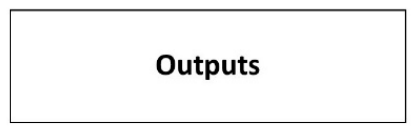

Scope: Identification and description of variation in character of the landscapes in the Eastern Mediterranean Region.

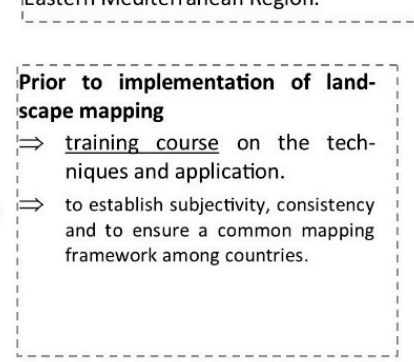

Figure 2. Common Working Framework for Landscape Character Mapping (LCM). Four day training was provided to all teams covering the basics of LCA process including GIS mapping, field validation and evaluation for decision-making and planning. 
Mapping procedure: During the implementation, the size of the digitized polygon and which landscape features considered as mappable (mapping unit), was among the most important issues arose during the mapping process. This was overcome by setting the minimum mapping unit (MMU) to $5 \mathrm{~km}^{2}$. Mapping was carried out at the 1:250,000 scale and successive GIS maps overlay of four definite variables (Table 1) was carried out for all study areas in order to produce Land Description Units (LDUs). LDUs are the largest homogeneous map unit sharing similar pattern of natural and cultural elements and they comprise the basis for further judgment and decision-making [16]. The procedure starts by dividing the area of interest into physiographic units from contour and geological data. More specifically a topographic map (contour lines of $20 \mathrm{~m}$ or $50 \mathrm{~m}$ ) is added in a GIS followed by a simplified geological map. During onscreen overlay the user defines significant relief variations based on the significant changes of form (distance of contour lines and variation of line shapes) and then delineates new polygons which integrate major geology changes in order to define landform units (combination of contour lines and geology). The resulting units are then further sub-divided by land cover and finally by settlement patterns to derive the LDUs. In every stage the unit is populated by the relevant value or class of each key attribute used. For example: unsettled, densely, medium or sparsely settled in the case of settlements. These units were subsequently amalgamated into Landscape Types (also termed Landscape Character Types - LCTs) with similar physical and cultural attributes [16]. Desk study in a GIS is a core part the landscape character mapping; in this case in an attempt to increased accuracy and speed in gathering landscape information we used Google Earth for reconnaissance purposes prior to fieldwork and for correcting LDUs boundaries following fieldwork. In addition, Google Earth imagery served for identifying current land use/land cover (LULC) thus allowing the refinement of LDUs, where up-to-date mapped data was not available.

Field Validation: Field survey was then carried out in order to validate all the information collated during desktop mapping and to confirm that LDUs corresponded to their mapped definition both thematically and in terms of actual boundaries. A standard field sheet was used in order to make and record observations in a systematic and consistent manner. This included information about the physical aesthetic and perceptual characteristics as well as a brief written description, which captured the overall impression of landscape character.

Typology: The developed typology i.e., nomenclature accounted for important elements, which characterize the Mediterranean landscapes mainly summarized in the following factors:

(A) Physical attributes: (i) geomorphology i.e., the inclusion of rugged terrain of hills and mountains, ravines and gorges, as well as plateaus was seen a necessary part of the typology (ii) coasts: MB has a long coast line while 3 out of 6 study areas border the sea, (iii) local distinctness: Fleshing out distinct types present at the national or case study level as described in Section 3.1.

(B) Cultural attributes: (i) Settlement pattern mainly reflected by villages and field pattern (ii) Landuse and land cover: a long history of human activity imprinted on land cover. For example the rangelands, reflecting the pastoral tradition [22-24] and shrublands (i.e., maquis or garrigue) also characteristic of the MB were incorporated.

Landscape Character Types (LCTs) from all countries were entered into a common database. Then, LCTs were subcategorized based on the prominent landform, LULC and settlement pattern (unsettled or settled). Afterwards, based on the description of each LCT an interactive, dynamic process took place, to identify similarities and repetitive patterns among national types. As a general rule, we used the Landform-Land-Use-Settlement pattern to create a broad Mediterranean typology, encompassing the various landscape types identified at Level 1 mapping of the pilot areas. The common EastMed Landscape Typology as derived from the national typologies is showed in the Appendix A.

\subsection{Landscape Complexity and Diversity}

In order to study the complexity of the study areas in terms of landscape types we employed five commonly employed landscape metrics for diversity, composition and configuration [2] namely LCT 
Richness (LCTR); Shannon's diversity index (SHDI), Shannon's evenness index (SHEI), Dominance, Mean Shape index (MSI). Indices were calculated at the landscape level [25] using V-Late 2.0 beta extension for GIS [26] and were chosen since the may be used for comparison between landscapes of different sizes.

\subsection{Statistical Analysis}

The Sørensen similarity coefficient Ss was employed in order to measure landscape types' similarity between study area pairs [27]:

$$
S_{s}=\frac{2 a}{2 a+b+c}
$$

where, $a=$ the number of common landscape types between two areas, $b=$ the number of landscape types unique to the first of the two areas and $c=$ the number of landscape types unique to the second area.

Also, in order to test if there are significant differences in the landscape variation among countries, and if those differences are due to their physical or cultural differentiation we first grouped the LDUs recorded in the six study areas in ten broader landform categories as well as in six broader land use categories. Then we applied the non-parametric K-independent Kruskal-Wallis test following a test for normality (Smirnov-Kolgomorov-Smirnov $p<0.05$ ) for the physical and cultural categories, taking into account the number of LDUs included in each category by country. We also run (log to log) linear regressions to examine the effect of area size on landscape diversity (response variable number of LDUs, number of types, SHFI and SHEI.

\section{Results}

\subsection{East Mediterranean Typology}

The highest similarities were between Cyprus and Lesvos, the two sites in Jordan (Mujib and Al Yarmouk), Lebanon and Epirus as well as Lebanon and the two sites in Jordan (SI > 0.4). The lowest similarities between Cyprus and the two sites in Jordan (Table 2).

Table 2. Landscape Types similarity among study sites based on Sørensen similarity coefficient.

\begin{tabular}{ccccccc}
\hline & Cyprus & Al Yarmouk & Mujib & Lebanon & Lesvos & Epirus \\
\hline Cyprus & & & & & & \\
Al Yarmouk & 0.09 & & & & & \\
Mujib & 0.04 & 0.46 & & & & \\
Lebanon & 0.22 & 0.46 & 0.31 & & \\
Lesvos & 0.46 & 0.13 & 0.12 & 0.17 & & \\
Epirus & 0.20 & 0.34 & 0.23 & 0.42 & 0.16 & \\
\hline
\end{tabular}

The landform character of landscapes in Cyprus and Lesvos is predominantly hilly, whereas in Epirus and Lebanon predominantly upland. The Jordanian study areas are dominated by plateaus. In terms of land use, the landscapes of Cyprus, Lesvos and Al Yarmouk are predominantly of agricultural character, in Mujib characterized by the extent of rangelands, while Lebanon and Epirus are predominantly of forested character (Figure 3).

A total number of 617 LDUs for a total of 69 landscape types at the East Mediterranean level was derived. The resulting East Mediterranean Landscape Typology consists of ten landscape classes based on prominent landform and six classes based on land use (Table 3; Figure 3). The predominant landform in the typology is hills (22\% of the types) followed by uplands ( $20 \%$ of the types) and mountains (13\% of the types). The predominant land use in the typology is agriculture ( $46 \%$ of the types) followed by forest ( $24 \%$ of the types) and rangelands (19\% of the types). There are also 18 types which are unique to the areas covered by this study. 

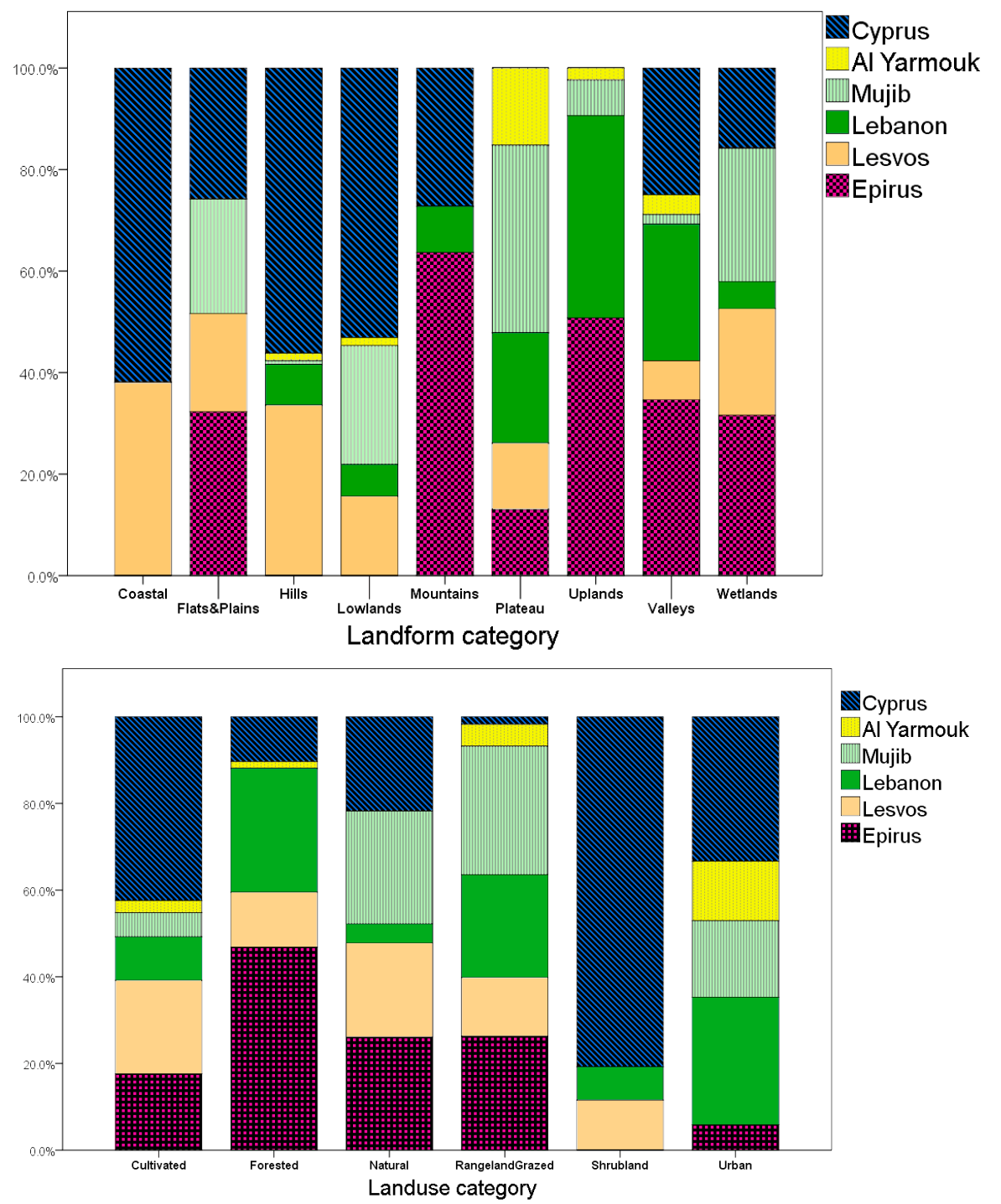

Figure 3. Landscape Profile of the study areas in terms of landuse and landform.

Table 3. Summary of the Eastern Mediterranean Typology.

\begin{tabular}{|c|c|}
\hline Total number of LDUs & 617 \\
\hline Total number of LCTs & 69 \\
\hline $\begin{array}{l}\text { Classes (categories) based on landform } \\
\text { (Total number) }\end{array}$ & $\begin{array}{l}\text { Hills, Valleys, Mountains, Uplands, Plateau, Coastal, Lowlands, Flats and Plains, } \\
\text { Wetlands, Urban (10) }\end{array}$ \\
\hline $\begin{array}{l}\text { Classes (categories) based on land use } \\
\text { (Total number) }\end{array}$ & Rangelands and Grazed, Shrubland, Forested, Cultivated, Vineyards, Arid (6) \\
\hline $\begin{array}{l}\text { Most common category based on landform } \\
\text { (No of LDUs) }\end{array}$ & Hills (137) \\
\hline $\begin{array}{l}\text { Most common category based on land use } \\
\qquad \text { (No of LDUs) }\end{array}$ & Urban (45), Shrubland (41) \\
\hline Most common LCT & Settled cultivated/agricultural lowlands \\
\hline Rare types (No of LDUs) & $\begin{array}{l}\text { Escarpments of the Dead Sea (1), Dead Sea (1), Salt flats (3), Water bodies (1), } \\
\text { River beds (4), Forested sparsely settled lowlands (1), Unsettled Forested Plateaus (1), } \\
\text { Settled Forested plateaus (1), Eroded plateau mixed farming (1), Settled High } \\
\text { (Alpine) Mountains (1), Unsettled mountain shrublands (1), Settled cultivated coastal } \\
\text { valley (1), Coastal dunes (1), Settled rangelands valley (1), Forested sparsely settled } \\
\text { lowlands (1), Unsettled lowland shrublands (1), Unsettled cultivated alluvial plains } \\
\text { (1), Unsettled plain rangelands (1). }\end{array}$ \\
\hline
\end{tabular}




\subsection{Landscape Diversity}

Cyprus with the largest studied area resulted in more mapped Land Description Units (210 in total) and consequently more landscape types (35). All studies areas are diverse, with Lebanon having the highest SHDI value (0.901). Dominance was higher in Cyprus (0.838) and lower in Lesvos (0.246) with the rest of the study areas having intermediate values. The LDUs in Lebanon, Yarmouk and Mujib study areas are the most complex in terms of Mean Shape Index (>2.2) (Table 4).

Table 4. Landscape Diversity in the six study areas.

\begin{tabular}{ccccccc}
\hline Area Analysis & Lesvos & Epirus & Mujib & Al Yarmouk & Lebanon & Cyprus \\
\hline Total Area in km $\mathrm{km}^{2}$ & 1795 & 3908 & 3800 & 1390 & 4757 & 9251 \\
Number of LDUs & 95 & 151 & 55 & 21 & 97 & 198 \\
\hline & Diversity & Analysis & & & & \\
\hline & 11 & 16 & 23 & 16 & 21 & 35 \\
& 2.152 & 2.28 & 2.601 & 2.321 & 2.742 & 2.717 \\
Landscape Character Type Richness (LCTR) & 0.897 & 0.822 & 0.83 & 0.837 & 0.901 & 0.764 \\
Shannon's Diversity (SHDI) & 0.246 & 0.493 & 0.534 & 0.452 & 0.303 & 0.838 \\
Shannon's Evenness (SHEI) & Form Analysis & & & \\
Dominance & 1.95 & 1.747 & 2.215 & 2.203 & 2.263 & 2.073 \\
\hline Mean Shape Index (MSI)
\end{tabular}

Statistical analysis results indicated that, apart from Mujib and Lesvos, for all other sites there was a statistical significant difference in the number of LDUs within the main land cover categories and the number of LDUs within the main landform categories (Table 5). In addition linear regressions showed that although most relationships between area and the components of diversity have medium to high predictive power only the relationship between area and landscape type richness was significant $(\mathrm{R} 2=0.73, p<0.05 ;$ Table 5$)$.

Table 5. Results for the statistical tests performed (K-Independent test between Land Description Units -LDUs, per site and Landform categories).

\begin{tabular}{|c|c|c|c|c|c|c|}
\hline & Cyprus & Al Yarmouk & Mujib & Lebanon & Lesvos & Epirus \\
\hline \multicolumn{7}{|c|}{ K-Independent test between LDUs per site and Landform categories } \\
\hline Chi-Square & 32.159 & 19.194 & 15.613 & 28.741 & 10.881 & 33.223 \\
\hline $\mathrm{df}$ & 9 & 9 & 9 & 9 & 9 & 9 \\
\hline Asymp. Sig. & 0.000 & 0.024 & 0.075 & 0.001 & 0.284 & 0.000 \\
\hline \multicolumn{7}{|c|}{ K-Independent test between LDUs per site and Landuse categories } \\
\hline Chi-Square & 25.578 & 17.659 & 18.620 & 12.416 & 10.566 & 14.598 \\
\hline $\mathrm{df}$ & 5 & 5 & 5 & 5 & 5 & 5 \\
\hline Asymp. Sig. & 0.000 & 0.003 & 0.002 & 0.030 & 0.061 & 0.012 \\
\hline \multicolumn{4}{|c|}{ Linear Regressions (log to $\log )$} & R2 & $\mathrm{F}$ & $\mathrm{P}$ \\
\hline \multicolumn{4}{|c|}{ LDUs against area } & 0.55 & 4.70 & 0.08 \\
\hline \multicolumn{4}{|c|}{ Landscape types against area } & 0.73 & 10.96 & $0.03 *$ \\
\hline \multicolumn{4}{|c|}{ SHDI against area } & 0.61 & 6.33 & 0.07 \\
\hline \multicolumn{4}{|c|}{ SHEI against area } & 0.25 & 1.31 & 0.31 \\
\hline
\end{tabular}

* statistically significant at the 0.05 level.

\section{Discussion}

The study has filled a gap in East Mediterranean landscape mapping and typology by setting a benchmark for landscape characterization work in the area, while at the same time, recognized and revealed the distinct landscape character of each study area and the inherent diversity of its landscapes. The typology produced resulted in sufficient variation to describe landscape types while it emphasized elements which are characteristic of Mediterranean landscapes. More specifically it has accounted for 
the coastal nature of the area, the variety of landforms and has incorporate settlement pattern and land use, in particular pastoral tradition the latter being an important element of Mediterranean land systems [22].

Although the pace of landscape characterization and mapping has been slower in the Mediterranean compared to Northern Europe there has been significant progress in recent years [20,28]). A comparison with the existing typologies which account for Mediterranean landscapes $[15,21]$ revealed that the first study identified 7 landscape types in the whole Mediterranean Basin while the second 11 landscape types at the 3rd level of classification. Thematically, although there is some correspondence, these are neither detailed nor eastern Mediterranean enough, to capture common as well as rare landscape types of the region as identified by the study. This is mainly due to the coarse mapping scale but also their geographical extent and scope (pan-European). For example, the extensive coastline is usually neglected in many regional and national land based typologies. This has led to the development of Seascapes Assessment and a call for treating islands as separate entities [28]. Rangelands are important elements of the landscapes, culturally and economically, in the Mediterranean and the study areas examined are no exception. Grazing may be year-round or seasonal (transhumance) — or even more sporadic in semi-desert areas. Low vegetation, often with small, spiny shrubs in combination with grasses and herbs have often been mapped as "bare land" in coarse land-use maps with the exception of recent work on Mediterranean land systems [22] in which 27 major land systems, not landscapes, were identified.

The high diversity of landscapes highlighted by our study is expected given the natural and cultural diversity of the study area. The work has identified and mapped a total of 69 landscape types (69) of which 18 rare. Rare landscape types (Table 3) are related to specific geomorphology or intensive anthropogenic activities which do not occur elsewhere in the region. The analysis of the landscape categories revealed statistically significant differences among countries apart from the landscape types with predominant landform of "Flats and Plains", which they were almost equally distributed among study sites. However, they were absent from Lebanon and Al Yarmouk. In addition, "Coastal" landscape types were present only in the cases of the two islands (Cyprus and Lesvos). "Mountainous" landscape types were found only in three study sites Cyprus, Lebanon and Epirus with the latter to have the highest percentage. In terms of land use categories, Shrubland is by far the most common landscape type in Cyprus; however, it was observed only in three study sites (Cyprus, Lebanon and Lesvos). All the other land use categories were found in all study sites with cultivated landscapes to be more abundant in Cyprus, forested landscapes in Epirus and grazed lands in Mujib.

Each study site shares common landscape types derived from common environmental and long human history in the area. The highest similarities were observed on the islands (Cyprus and Lesvos) and the mountainous areas (Lebanon and Epirus), which were then followed by the similarity of the latter to Cyprus, due to the mountainous character of the island itself. However, within each study site, distinctive LCTs were derived, which were originated from the particular conditions prevailing in each country and involve both physical such as "Arid" or "Dead Sea" special character types and anthropogenic ones like "Artificial settled hills" in Lebanon.

While Lesvos and Al Yarmouk are comparable in area, they demonstrated a large divergence in their number of LDUs. This suggests that LDUs are generally larger in Yarmouk and more irregularly shaped as indicated by the higher MSI value. Although smaller, Yarmouk has higher LCT richness unevenly distributed as indicated by the higher dominance value. Mujib is comparable to Epirus and Lebanon study areas, in terms of area extent with fewer LDUs and the highest LCT richness among the three. This suggests that LDUs are larger and irregularly shaped (as indicated by the MSI) while the distribution of area among LCTs is uneven, i.e., a few LCTs are dominant. Cyprus, the largest in extent study area, has the largest number of LDUs and the highest richness of LCTs. The island demonstrates the highest dominance value (ergo the lowest SHEI) compared to the rest study areas suggesting that the distribution among different LCTs is more uneven and therefore a few LCTs dominate the landscape in Cyprus. The lower dominance values in Lesvos and Lebanon 
indicate that LCTs cover equal surfaces in these case studies. Complexity of a landscape as expressed by its shape (quantified by MSI) reflects boundaries between semi-natural areas, but also management in cultural landscapes. Simple shapes is the norm for agricultural and pastoral landscapes while on mountain or other landscapes dominated by landform or geology boundary types might be more abrupt. In our case, MSI values among study sites are very close demonstrating similarity on the range and types of boundaries present.

Regression showed that landscape diversity (expressed by the number of landscape types and SHDI) is area dependent i.e., the largest the area the highest the landscape diversity. The relationship seems to be analogous to the species-area curve [29]. However, when examining evenness against area size there is no trend since SHEI measures the distribution of area among patch i.e., in this case LDU types. The use of Shannon index for assessing landscape diversity is recommended since it is sensitive to rare landscape types and therefore appropriate for landscape management within an ecological framework [30]. The highest number of landscape types recorded in Cyprus compared to the rest of the study areas should not be attributed only to its size but also to the fact that we mapped the whole range of landscapes within the island's geographical boundaries. Landscape diversity comparisons among regions depend usually on the landscape itself, but also on the way that the methodology has been applied in each region. Despite the effort to streamline the process we cannot exclude elements of subjectivity in the application of the landscape character mapping by the teams involved. In terms of characterization, the findings imply that the 'complexity' of the classification scheme (should) increase as the area increases.

The problems of cross comparison between countries has been addressed by other studies $[13,17]$. In the absence of truly unified datasets for the whole area the study relied on nationally available datasets which differed in nomenclature and classification systems. Data issues (availability, accessibility and quality) along with problematic access to some parts of the study areas due to safety and security reasons was also a limitation in addition to semantics in the interpretation of landform types, settlements, and the very term landscape. However, and despite the diverse background of the persons involved in the study, training and protocol development brought the teams closer than before to a common understanding of methods and terms. In the same way that sampling units assist when comparing population samples, a consistent landscape mapping framework can have a similar role when comparing landscape types.

\section{Conclusions}

Landscape mapping and identification, a prerequisite for countries signatories to the ELC, is a means to inform landscape planning, develop strategies for landscape conservation and enhancement, or to provide outputs which can be used with other decision-making tools such as Environmental Impact Assessment. For example whereas previously, Greece and Cyprus had recognized a number of outstanding landscapes and landscape features as worthy of protection, they now need to address in their spatial planning all types of landscapes, whether these are outstanding, "every-day" or even degraded and in need of attention. Therefore identifying the variety of landscapes within a country's geographical boundaries is the first step towards landscape oriented planning. The landscape types identified herein form by no means an exhaustive list with the exception of Lesvos and Cyprus, since we did not map the whole range of landscapes within the countries geographical boundaries. The development of the typology requires the sampling of the whole range of landscape units in a geographical area in order to identify the attributes that discriminate between the full complements of landscape types. However, the framework devised herein can be used for a range of applications (ecological, cultural, planning) and has already been adopted by the relevant Planning Departments in Cyprus and Lebanon through their Local/Regional Development Plans. In addition it can assist with infusing ELC principles beyond European boundaries and with the development of a Mediterranean-wide landscape typology as a common language for monitoring landscape changes in a very dynamic and fragile region of the world. 
Acknowledgments: This work was partly funded by the MEDSCAPES project (ENPI-CBCMED program). We would like to thank the MEDSCAPES team for providing access to datasets.

Author Contributions: The idea was a product of discussions between the authors. Ioannis Vogiatzakis wrote the manuscript while Paraskevi Manolaki carried out the statistical analysis and contributed with comments to all versions of the manuscript.

Conflicts of Interest: The authors declare no conflict of interest.

\section{Appendix A}

Table A1. $\mathrm{LEB}=$ Lebanon, $\mathrm{ALYAR}=\mathrm{Al}$ Yarmouk, $\mathrm{CY}=$ Cyprus, $\mathrm{LES}=$ Lesvos, MUJ $=$ Mujib, EPIR = Epirus).

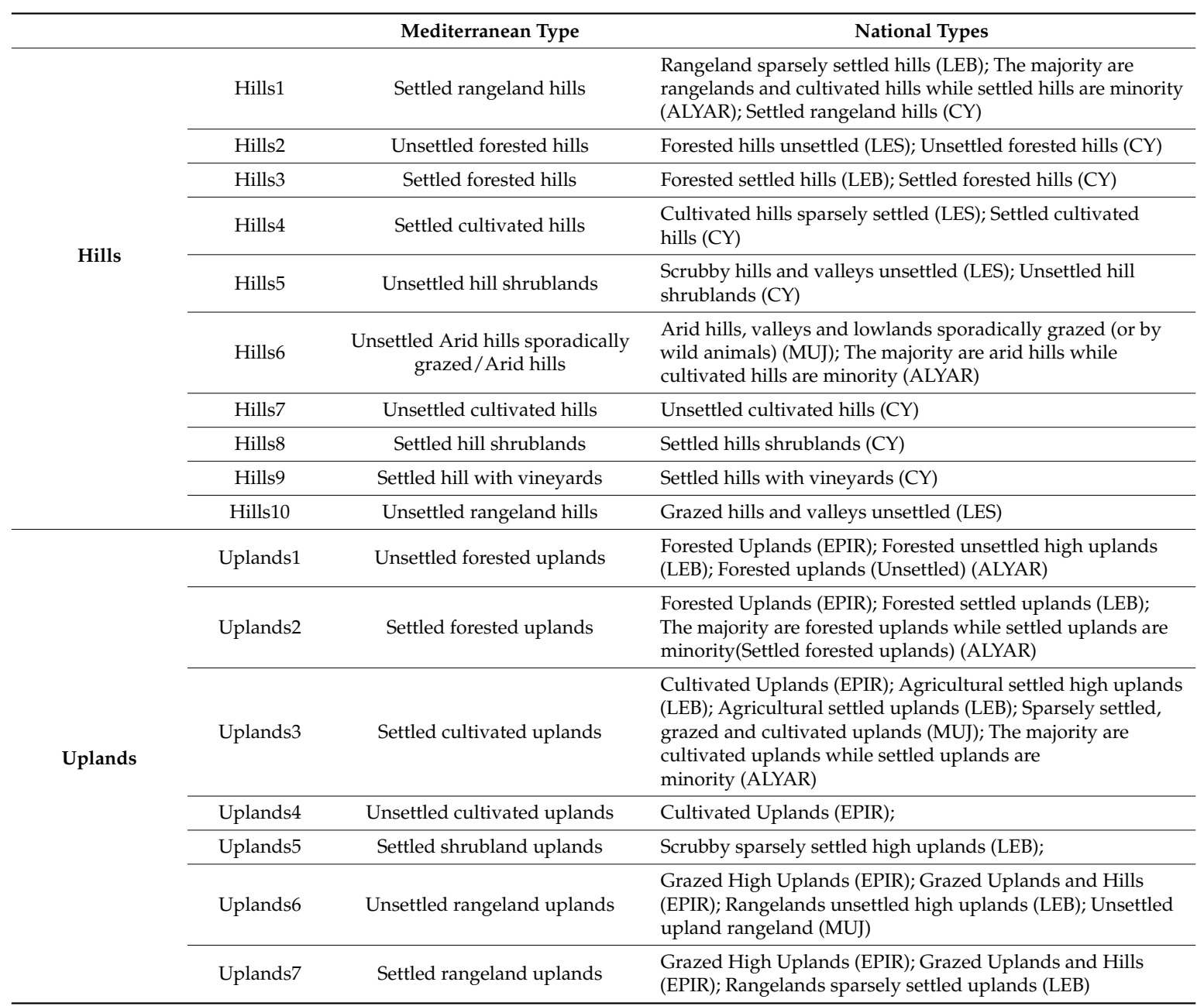


Table A1. Cont.

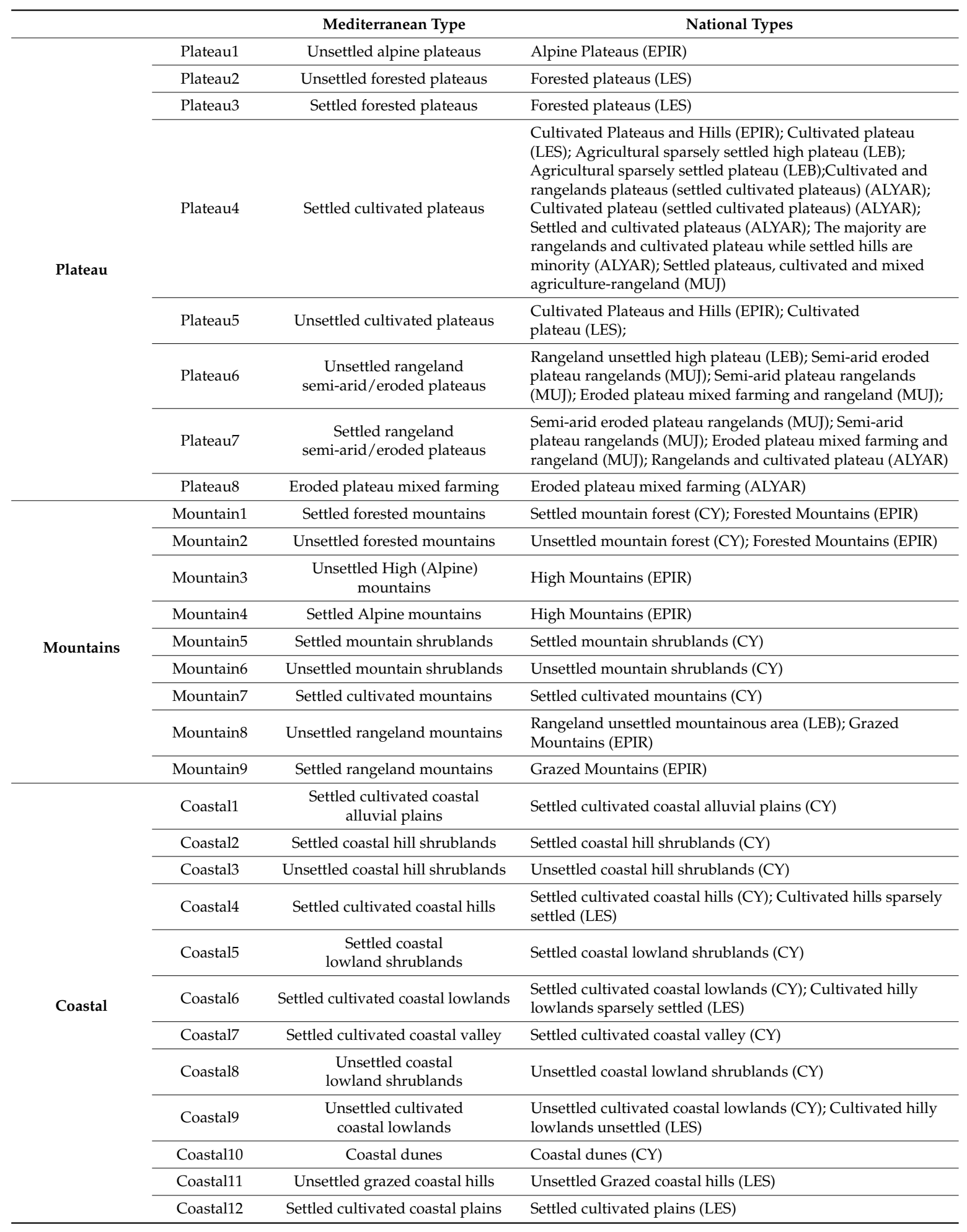


Table A1. Cont.

\begin{tabular}{|c|c|c|c|}
\hline & & Mediterranean Type & National Types \\
\hline \multirow{4}{*}{ Valley } & Valley1 & Settled forested valley & $\begin{array}{l}\text { Settled forested valley (CY); Forested Valleys (EPIR); Forested } \\
\text { sparsely settled valley (LEB) }\end{array}$ \\
\hline & Valley3 & Settled cultivated valleys & $\begin{array}{l}\text { Settled cultivated valley (CY); Cultivated Valleys (EPIR); } \\
\text { Cultivated valleys (LES); Agricultural sparsely settled valley } \\
\text { (LEB); Cultivated valley floors and river terraces (ALYAR) }\end{array}$ \\
\hline & Valley5 & Unsettled deep valleys & $\begin{array}{l}\text { Unsettled ravine shrublands (CY); Deep Ravines (EPIR); } \\
\text { Unsettled deep valleys and ravines (MUJ) }\end{array}$ \\
\hline & Valley6 & Settled valley rangelands & $\begin{array}{l}\text { The majority are valley rangelands while the settled valley are } \\
\text { minority (ALYAR) }\end{array}$ \\
\hline \multirow[t]{4}{*}{ Lowlands } & Lowlands3 & Settled cultivated lowlands & $\begin{array}{l}\text { Settled cultivated lowlands (CY); Agricultural sparsely settled } \\
\text { lowlands (LEB); Cultivated hills lowlands sparsely } \\
\text { settled (LES) }\end{array}$ \\
\hline & Lowlands4 & Unsettled lowland rangelands & $\begin{array}{l}\text { Rangelands/lowland/unsettled (ALYAR); Unsettled lowland, } \\
\text { hill and valley rangelands, regularly/seasonally grazed (MUJ) }\end{array}$ \\
\hline & Lowlands5 & $\begin{array}{l}\text { Settled cultivated } \\
\text { alluvial lowlands }\end{array}$ & Settled cultivated alluvial lowlands (CY) \\
\hline & Lowlands6 & Unsettled lowland shrublands & Unsettled lowland shrublands (CY) \\
\hline \multirow{2}{*}{ Wetlands } & Wetlands1 & Coastal wetlands & Coastal Wetlands (CY); Coastal wetlands (LES) \\
\hline & Wetlands2 & Lakes & Lakes (EPIR) \\
\hline \multirow{5}{*}{ Flats \& Plains } & Flats\&Plains1 & Settled cultivated plains & $\begin{array}{l}\text { Settled cultivated plains (MUJ); Settled cultivated plains (LES); } \\
\text { Cultivated Plains (EPIR) }\end{array}$ \\
\hline & Flats\&Plains2 & Unsettled cultivated plains & Cultivated Plains (EPIR) \\
\hline & Flats\&Plains3 & Settled cultivated alluvial plains & Settled cultivated alluvial plains (CY) \\
\hline & Flats\&Plains4 & $\begin{array}{l}\text { Unsettled cultivated } \\
\text { alluvial plains }\end{array}$ & Unsettled cultivated alluvial plains (CY) \\
\hline & Flats\&Plains5 & Unsettled rangeland plains & Unsettled plain rangelands (MUJ) \\
\hline Urban & Urban & Urban & $\begin{array}{l}\text { Urban Areas (EPIR); Urban (CY); Settled plateau (ALYAR); } \\
\text { Settled uplands (ALYAR); Artificial settled hills (LEB); } \\
\text { (Artificial) Urbanized lowlands (LEB) }\end{array}$ \\
\hline
\end{tabular}

\section{References}

1. Odum, E.P. Great ideas in ecology for the 1990s. BioScience 1992, 42, 542-545. [CrossRef]

2. Forman, R.; Godron, M. Landscape Ecology; John Wiley: New York, NY, USA, 1986.

3. Council of Europe/UNEP \& Environmental Centre for Nature Conservation. The Pan-European Biological and Landscape Diversity Strategy. A Vision for Europe's Natural Heritage; Council of Europe Press: Strasbourg, France, 1996.

4. Vogiatzakis, I.N.; Pungetti, G.; Mannion, A. (Eds.) Mediterranean Island Landscapes: Natural and Cultural Approaches; Landscape Series; Springer Publishing: New York, NY, USA, 2008; Volume 9.

5. Grove, A.T.; Rackham, O. The Nature of Mediterranean Europe: An Ecological History; Yale University Press: London, UK, 2001.

6. Blondel, J.; Aronson, J.; Bodiou, J.-Y.; Boeuf, G. The Mediterranean Region: Biological Diversity in Space and Time; Oxford University Press: Oxford, UK, 2010. 
7. Athanassopoulos, E.F.; Wandsnider, L. (Eds.) Mediterranean Archaeological LandscapesCurrent Issues; University of Pennsylvania Press: Philadelphia, PA, USA, 2004.

8. Mazzoleni, S.; Di Pasquale, G.; Mulligan, M.; Di Martino, P.; Rego, F. (Eds.) Recent Dynamics of the Mediterranean Vegetation and Landscape; John Wiley \& Sons: New York, NY, USA, 2004.

9. IUCN. Guidelines for Protected Area Management Categories; CNPPA with the assistance of WCMC; IUCN: Gland, Switzerland; Cambridge, UK, 1994.

10. Vogiatzakis, I.; Papayannis, T.; Mannion, A.M. Political landscapes of Mediterranean islands. In Mediterranean Island Landscapes; Vogiatzakis, I.N., Pungetti, G., Mannion, A.M., Eds.; Springer: New York, NY, USA, 2008; pp. 100-114.

11. Stanners, D.; Bourdeau, P. Europe's Environment: The Dobris Assessment; European Environment Agency: Copenhagen, Denmark, 1995.

12. European Landscape Convention. Available online: https://rm.coe.int/16800805ce (accessed on 19 October 2017).

13. Washer, D.; Jongman, R. (Eds.) European Landscapes: Classification, Evaluation and Conservation; Environment Technical Reports; European Environment Agency: Copenhagen, Denmark, 2003.

14. Jongman, R.H.G.; Bunce, R.G.H.; Metzger, M.J.; Mücher, C.A.; Howard, D.C.; Mateus, V.L. Objectives and applications of a statistical environmental stratification of Europe. Landsc. Ecol. 2006, 21, 409-419. [CrossRef]

15. Mücher, C.A.; Klijn, J.A.; Wascher, D.M.; Schaminée, J.H.J. A new European Landscape Classification (LANMAP): A transparent, flexible and user-oriented methodology to distinguish landscapes. Ecol. Indic. 2010, 10, 87-103. [CrossRef]

16. Warnock, S.; Griffiths, G.H. Landscape Characterisation: The Living Landscapes approach in the UK. Landsc. Res. 2015, 40, 261-278. [CrossRef]

17. Hazeu, G.W.; Metzger, M.J.; Mücher, C.A.; Perez-Soba, M.; Renetzeder, C.H.; Andersen, E. European environmental stratifications and typologies: An overview. Agric. Ecosyst. Environ. 2011, 142, 29-39. [CrossRef]

18. Brabyn, L. Landscape classification using GIS and national digital databases. Lands. Res. 1996, 21, $277-300$. [CrossRef]

19. Groom, G.; Wascher, D.; Potschin, M.; Haines-Young, R. Landscape character assessments and fellow travellers across Europe: A review. In Landscape Ecology in the Mediterranean: Inside and Outside Approaches; Bunce, R.G.H., Jongman, R.H.G., Eds.; IALE Publication Series: Faro, Portugal, 2006; Volume 3, pp. 227-231.

20. Vogiatzakis, I.N. Mediterranean experience and practice in Landscape Character Assessment. Ecol. Med. 2011, 37, 17-31.

21. Meeus, J.H.A. Pan-European landscapes. Landsc. Urban Plan. 1995, 31, 57-79. [CrossRef]

22. Malek, Ž.; Verburg, P. Mediterranean land systems: Representing diversity and intensity of complex land systems in a dynamic region. Landsc. Urban Plan. 2017, 165, 102-116. [CrossRef]

23. Le Houerou, H.N. Impact of man and his grazing animals. In Ecosystems of the World 11: Mediterranean Type-Shrublands; Di Castri, F., Goodall, D.W., Sprecht, R.L., Eds.; Elsevier: Amsterdam, Netherlands, 1981.

24. Papanastasis, V.P.; Chouvardas, D. Application of the state-and-transition approach to conservation management of a grazed Mediterranean landscape in Greece. Israel J. Plant Sci. 2005, 53, 191-202. [CrossRef]

25. Lang, S.; Tiede, D. vLATE Extension für ArcGIS-Vektorbasiertes Tool zur quantitativen Landschaftsstrukturanalyse. Available online: https:/ / sites.google.com/site/largvlate/gis-tools/v-late (accessed on 19 October 2017).

26. McGarigal, K. Fragstats: Spatial Pattern Analysis Program for Categorical Maps; User Manual; University of Massachusetts: Amherst, MA, USA, 2015.

27. Kent, M. Vegetation Description and Data Analysis: A Practical Approach, 2nd ed.; Wiley: New York, NY, USA, 2012.

28. Vogiatzakis, I.N.; Zomeni, M.; Mannion, A.M. Characterizing Islandscapes: Conceptual and Methodological Challenges Exemplified in the Mediterranean. Land 2017, 6, 14. [CrossRef]

29. MacArthur, R.H.; Wilson, E.O. The theory of Island Biogeography; Princeton University: Princeton, NJ, USA, 1967.

30. Nagendra, H. Opposite trends in response for the Shannon and Simpson indices of landscape diversity. Appl. Geogr. 2002, 22, 175-186. [CrossRef]

(C) 2017 by the authors. Licensee MDPI, Basel, Switzerland. This article is an open access article distributed under the terms and conditions of the Creative Commons Attribution (CC BY) license (http:/ / creativecommons.org/licenses/by/4.0/). 